Roman, Frederick W. The Industrial and Commercial Schools of the United States and Germany. Pp. xv, 382. Price, \$1.50. New York: G. P. Putnam's Sons, 1915.

A comparative study, full of informative detail. Those interested in vocational education and continuation schools will read the book in its entirety. To others it will be particularly serviceable as a reference work.

Somner, Willuam Graham. (Ed. by Albert G. Keller.) The Challenge of Facts and Other Essays. Pp. xii, 450. Price, \$2.25. New Haven: Yale University Press, 1914.

For this third volume of the late Professor Sumner's writings we are indebted to the careful and persistent research of his associate, Professor Albert Galloway Keller.

At least five of these essays are here printed for the first time, so far as Professor Keller can discover. The twenty-five others had become inaccessible. It is obviously impossible to attempt in a review even to outline the ground covered by the author in such varied fields as are indicated in some of the subjects: In Reply to a Socialist, Who Win by Progress, Federal Legislation on Railroads, Democracy and Responsible Government, Foreword to Lynch-Law. One can only express his amazement that so busy a man as Professor Sumner managed to do all of this work. One must be equally impressed by the modesty revealed in the fact that he allowed much of it to go unpublished. Professor Keller is to be congratulated for collecting and publishing the essays of one of the most interesting and virile teachers of his time.

\title{
POLITICAL AND GOVERNMENTAL PROBLEMS
}

DeWrtw, Benjamin Parke. Progressive Movement. Pp. xii, 376. Price, $\$ 1.50$. New York: The Macmillan Company, 1915.

This book is more than a eulogy of the progressive party. The author realizes there are men in all parties who are trying to place the government more fully within the control of the community and to make it more serviceable to the community at large and especially to those who are laboring under economic disadvantages. He describes this movement within the various political parties in recent times and then takes up in turn the national, state and city governments in order to show the most important efforts which have been made within recent years to entrust the government to more representative men, to improve its structure or to increase its usefulness. While he exhibits strong sympathy with the progressive party, he usually tries to be non-partisan, and he states the results of his studies in a most interesting manner.

The discussion of popular control of the government, however, is extremely weak. The word "politician" is used frequently and only in a disparaging manner. The author nowhere shows that he realizes that the running of our government requires, in addition to the services which our public officials render as such, the expenditure on the part of a large number of men of an amount of thought, time and energy which is far greater than can be expected from the 
average citizen, that such an expenditure is not in itself an evil but is essential, that the inducing of sufficient men of the right type to make this expenditure is the main difficulty in any real reform movement, and that undiscriminating abuse of those who do this work adds to the difficulty and injures the cause of good government.

The author deplores the fact that in some places it is necessary to have watchers at the polls on election days and says that policemen should be substituted. He fails to realize that the work done on election day is only a very small part of the work done in a campaign by men who have strong convictions and who make practical efforts to have those convictions adopted by the electorate. His opinion that police supervision would be sufficient is amusing. The reviewer himself has been obliged to keep from voting a man who did not live in the division but who was brought to the polling-place by a policeman, and he has caught another policeman repeatedly violating the election law. Both policemen had secured their positions by the method which is said to secure efficient and faithful public service. They were no worse than many other members of the force.

The book has, it is true, many good features. But it does not show that acquaintance with political conditions which is essential to an adequate discussion of our system of government.

\section{Philadelphia.}

Robert P. ReEder.

Mclatghlin, Andrew C. and Hart, Albert Bushnell. Cyclopedia of American Government. (3 vols.) Pp. xxxiii, 2290. Price, \$22.50. New York: D. Appleton and Company, 1914.

The classic example of the old lady who was well informed on such subjects as those which began with the letters $A$ to $D$, but none others, because she had not read further in the encyclopedia, does not apply to reviewers of such works. It is a safe prediction that reviewers of encyclopedias, academic or otherwise, either sit down immediately and read critically a few sections or use the encyclopedia as a reference work for a time and then give their judgment resulting from this use. The author of this review has used the latter method.

As tested by a year of use, the reviewer feels that this encyclopedia is one that will be of material assistance to all students of government as a ready-at-hand reference work. Even on those subjects that come within the owner's specialty, the encyclopedia will offer at least a bibliography of secondary and original material that will almost invariably prove suggestive and valuable. And aside from one's specialty, the encyclopedia presents concise, readable articles of both general and informational value. The articles, as a rule, are not evasive, but concise and "meaty." What this means with reference to the mass of detailed, practical information presented in its 3,000 pages is barely suggested when one is told that the index alone refers to 13,500 topics.

The authors, Professors Andrew C. McLaughlin and Albert Bushnell Hart, have surely realized their ambition to present a work that will supply "the need for a usable, succinct and comprehensive presentation of practical, actual and theoretical government in America" of particular use not so much to the specialists who will be aided by the discussion of subjects in neighboring fields as to the 